\title{
Pengembangan Kecerdasan Kinestetik Peserta Didik Melalui Kegiatan Ekstrakurikuler Tari Tradisional di Madrasah Ibtidaiyah Unggulan Al-Islah Kecamatan Muncar Kabupaten Banyuwangi
}

\author{
Dyah Ayu Pangarsi Putri \\ IAIN Jember \\ dyahayupangarsiputri@gmail.com \\ Lailatul Usriyah \\ IAIN Jember \\ lailatulusriyah78@gmail.com
}

\begin{abstract}
Abstrak
Madrasah Ibtidaiyah Unggulan Al-Islah Muncar Banyuwangi adalah sekolah swasta yang pada bulan Januari 2018 mulai menerapkan kegiatan ekstrakurikuler tari tradisional dengan alasan untuk mengembangkan salah satu potensi yang dimiliki peserta didik yaitu kecerdasan kinestetik. Fokus penelitian ini: 1) Bagaimana pengembangan kecerdasan kinestetik peserta didik melalui kegiatan ekstrakurikuler unsur wiraga tari tradisional di Madrasah Ibtidaiyah Unggulan Al-Islah Kecamatan Muncar Kabupaten Banyuwangi tahun pelajaran 2018/2019? 2) Bagaimana pengembangan kecerdasan kinestetik peserta didik melalui kegiatan ekstrakurikuler unsur wirama tari tradisional di Madrasah Ibtidaiyah Unggulan Al-Islah Kecamatan Muncar Kabupaten Banyuwangi tahun pelajaran 2018/2019? 3) Bagaimana pengembangan kecerdasan kinestetik peserta didik melalui kegiatan ekstrakurikuler unsur wirasa tari tradisional di Madrasah Ibtidaiyah Unggulan Al-Islah Kecamatan Muncar Kabupaten Banyuwangi tahun pelajaran 2018/2019? Hasil penelitian menunjukkan bahwa: 1) Meliputi, dengan pengenalan gerak dasar tari, pembiasaan senam pemanasan, latihan gerakan-gerakan tari tradisional dan perkembangannya dapat menguasai bagian-bagian tubuh ketika menari. 2) Meliputi, mengatur cepat lambatnya gerakan menggunakan hitungan dan perasaan, mengatur antara pergantian gerakan disaat musik yang tepat dengan menggunakan hitungan, mengatur keselarasan antara pukulan musik dengan gerakan-gerakan agar terdengar lebih mantap dengan menggunakan hitungan dan perasaan, dan perkembangannya dapat menyeimbangkan gerakan tari dengan alunan
\end{abstract}


musik. 3) Dengan pembiasaan senam senyum selama beberapa menit agar terbiasa berkspresi tersenyum ketika menari, dan perkembangannya dapat terbiasa berekspresi tersenyum ketika menari.

\section{Kata kunci: Kecerdasan Kinestetik; Kegiatan Ekstrakurikuler Tari Tradisional}

\section{PENDAHULUAN}

Kegiatan ekstrakurikuler dalam dunia pendidikan merupakan kegiatan yang dilakukan di luar kelas dan di luar jam pelajaran. Kegiatan ini dilakukan di bawah bimbingan dan pengawasan satuan pendidikan, yang bertujuan untuk mengembangkan potensi, bakat, minat, kemampuan, kepribadian, kerja sama, dan kemandirian peserta didik secara optimal untuk mendukung pencapaian tujuan pendidikan. ${ }^{1}$

Hal tersebut sesuai dengan Undang-Undang No. 20 Tahun 2003 tentang Sistem Pendidikan Nasional Bab 1 Pasal 3 yang menyatakan bahwa:

Pendidikan Nasional berfungsi mengembangkan kemampuan dan membentuk watak serta peradaban bangsa yang bermartabat dalam rangka mencerdaskan kehidupan bangsa, bertujuan untuk berkembangnya potensi peserta didik agar menjadi manusia yang beriman dan bertaqwa kepada Tuhan Yang Maha Esa, berakhlak mulia, sehat, berilmu, cakap, kreatif, mandiri, dan menjadi warga negara yang demokratis serta bertanggung jawab. $^{2}$

Berdasarkan Undang-Undang tersebut, jelas bahwa pengembangan potensi peserta didik sebagaimana dimaksud dalam tujuan pendidikan nasional tersebut dapat diwujudkan melalui kegiatan ekstrakurikuler. ${ }^{3}$ Sedangkan salah satu potensi yang dimiliki peserta didik dan dapat dikembangkan melalui kegiatan ekstrakurikuler yaitu potensi kecerdasan,

\footnotetext{
${ }^{1}$ Trianto Ibnu Badar At-Taubany, Desain Pengembangan Kurikulum 2013 di Madrasah (Depok: Kencana, 2017), 334.

${ }^{2}$ Undang-Undang SISDIKNAS (Sistem Pendidikan Nasional) UU RI No. 20 Th. 2003 (Jakarta: Sinar Grafika, 2008), 7.

${ }^{3}$ At-Taubany, Desain Pengembangan Kurikulum 2013 di Madrasah, 333
} 
dimana kecerdasan merupakan kemampuan seseorang untuk memecahkan persoalan yang nyata dan dalam situasi yang bermacam-macam. ${ }^{4}$

Menurut Howard Gardner, ada delapan macam kecerdasan yang dimiliki oleh manusia, salah satunya yaitu kecerdasan kinestetik atau kecerdasan olah tubuh karena dapat merangsang kemampuan seseorang untuk mengolah tubuh atau untuk mengekspresikan gagasan dan emosi melalui gerakan. Kemampuan seperti ini dapat diamati pada anak yang pandai berolahraga dan menari atau berdansa. ${ }^{5}$ Kecerdasan kinestetik peserta didik sangat perlu untuk dikembangkan dengan pendekatan yang baik dan benar. Keseriusan, ketekunan, dan kemauan keras untuk melakukan dan menunjukkan yang terbaik adalah bagian dari kunci mencapai kecerdasan kinestetik yang setinggi-tingginya, karena kecerdasan setiap orang bisa dikembangkan sebesar-besarnya jika ada kemauan untuk mengembangkannya. ${ }^{6}$

Mengenai salah tujuan kegiatan ekstrakurikuler tari tradisional tersebut yaitu untuk mengembangkan kecerdasan kinestetik peserta didik atau kemampuan olah tubuh. Jadi kegiatan menari merupakan tidak lain dari sebuah kegiatan olahraga yang dapat menyehatkan tubuh, mengembangkan olah tubuh, serta mengembangkan ketrampilan. Hal tersebut sesuai dengan hadits riwayat Ibnu Majah mengenai olah tubuh dan ketrampilan, yang menyatakan bahwa: ${ }^{7}$

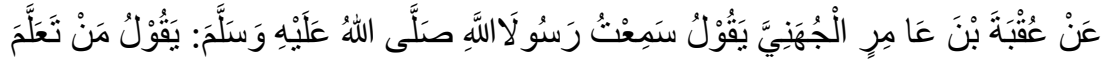

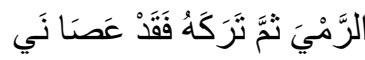

Artinya: "Dari Uqbah bin Amirul Juhani, Rasulullah Saw bersabda: "Siapa yang belajar memanah kemudian meninggalkannya maka dia telah membangkang padaku." (HR. Ibnu Majah)

${ }^{4}$ Baharuddin, Teori Belajar \& Pembelajaran (Yogyakarta, Ar-Ruzz Media, 2015), 201.

${ }^{5}$ Ibid., 17.

${ }^{6}$ Ibid., 4.

${ }^{7}$ Alaik S, 40 Hadits Shahih Teladan Hidup Sehat Rasulullah (Yogyakarta: Pustaka Pesantren, 2011), 28. 
Dalam hadits tersebut menjelaskan tentang pentingnya olahraga bagi kita semua. Walaupun hal itu tidak diungkapkan secara tegas oleh beliau dengan menggunakan kata "olahraga" karena memang kata itu belum dikenal di masa orang Arab pada waktu itu, tetapi makna yang terkandung dalam hadits di atas memiliki keserupaan dengan olahraga pada umumnya. Jadi jadi anjuran untuk berolahraga ini tidak lain agar memiliki tubuh yang kuat dan sehat, sehingga dapat optimal beribadah kepada Allah. Untuk konteks sekarang, tentu saja wujud dan model olahraganya tidak serupa. Misalnya saja kegiatan olahraga yang berwujud dalam kegiatan menari tari tradisional ini.

Kegiatan ekstrakurikuler tari tradisional tersebut masih dilaksanakan sejak awal tahun 2018 tepatnya bulan Januari. Dikarenakan kegiatan tersebut masih dilaksanakan baru-baru ini, pastinya memperlihatkan bagaimana akan proses yang mengajarkan mulai dari nol hingga selanjutnya. Kegiatan ini dilaksanakan dalam satu minggu satu kali dan di luar jam pelajaran yaitu pada hari minggu mulai dari pagi sampai siang yang diikuti oleh beberapa peserta didik dari kelas 1 sampai kelas 5. Tujuan dari kegiatan ini yaitu untuk mengembangkan potensi yang ada di dalam peserta didik. Dan salah satu potensi yang bisa dikembangkan melalui kegiatan ekstrakurikuler tari tradisional ini adalah kecerdasan kinestetik atau kemampuan olah gerak peserta didik.

Kegiatan ekstrakurikuler tari tradisional di Madrasah Ibtidaiyah Unggulan Al-Islah Muncar ini merupakan kegiatan pengembangan kemampuan koordinasi gerak tubuh dengan pikiran dimana agar bisa berkembang secara maksimal sehingga nantinya mampu mengikuti kompetisi yang ada di dalam maupun di luar sekolah. Selain itu juga diharapkan peserta didik dapat menambah pengetahuan, wawasan, serta kecintaan terhadap kebudayaan yang ada. Tidak semua sekolah menerapkan kegiatan seperti ini. Umumnya sekolah-sekolah hanya melaksanakan kegiatan tari sekilas materi saat pelajaran. Dari jumlah 15 Madrasah 
Ibtidaiyah di Kecamatan Muncar, hanya Madrasah Ibtidaiyah Unggulan AlIslah yang memiliki kegiatan ekstrakurikuler tari khususnya tari tradisional. Dimana peserta didiknya tidak hanya diajarkan tentang tari saat materi saja, tetapi juga diajarkan secara langsung dan dipraktekkan dengan sempurna. ${ }^{8}$

Berdasarkan latar belakang yang telah dikemukakan di atas, maka peneliti tertarik untuk melakukan sebuah penelitian yang berjudul "Pengembangan Kecerdasan Kinestetik Peserta Didik Melalui Kegiatan Ekstrakurikuler Tari Tradisional di Madrasah Ibtidaiyah Unggulan Al-Islah Kecamatan Muncar Kabupaten Banyuwangi Tahun Pelajaran 2018/2019”

\section{METODE PENELITIAN}

Peneliti ini menggunakan pendekatan kualitatif dengan jenis deskriptif, hal ini dikarenakan peneliti ingin mengetahui permasalahan yang terjadi secara mendalam dan menyeluruh dari objek yang diteliti, serta mengetahui secara mendalam dengan menggambarkan secara sistematis berdasarkan fakta di lapangan dalam bentuk deskriptif.

Adapun yang menjadi lokasi penelitian ini dilakukan yaitu Madrasah Ibtidaiyah Unggulan Al-Islah Kecamatan Muncar Kabupaten Banyuwangi. Alasan peneliti memilih lokasi penelitian di Madrasah Ibtidaiyah Unggulan Al-Islah merupakan sekolah yang memberikan perhatian terhadap pengembangan kecerdasan kinestetik pada peserta didik melalui kegiatan ekstrakurikuler tari khususnya tari tradisional yang ada di Kecamatan Muncar. Dan sekolah tersebut sudah mendapatkan prestasi yaitu juara 2 tari gandrung tingkat kecamatan.

Subyek penelitian yang dijadikan informan ditentukan menggunakan purposive sampling. Purposive sampling adalah teknik pengambilan sampel sumber data dengan pertimbangan tertentu. ${ }^{9}$ Pertimbangan tertentu ini

\footnotetext{
${ }^{8}$ Masrukah, Wawancara, Banyuwangi, 18 Januari 2019.

9 Sugiyono, Metode Penelitian Kuantitatif Kualitatif dan R\&D (Bandung: Alfabeta, 2016), 216.
} 
adalah orang yang akan dijadikan informan yaitu orang yang dapat memberikan informasi berupa data yang diperlukan oleh peneliti.

Berdasarkan uraian tersebut, yang dijadikan sebagai subyek penelitian ini adalah:

1. Kepala Madrasah

2. Guru pembimbing kegiatan ekstrakurikuler tari tradisional

3. Peserta didik yang mengikuti kegiatan ekstrakurikuler tari tradisional

Adapun teknik yang digunakan untuk mengumpulkan data dalam penelitian ini adalah teknik observasi, teknik wawancara dan teknik dokumentasi. Sedangkan analisis data dalam penelitian ini menggunakan analisis menurut Miles, Huberman, dan Saldana, yakni analisis data dalam penelitian kualitatif terdapat tiga alur aktivitas/kegiatan secara bersamaan. Aktivitas yang terjadi yaitu: kondensasi data, penyajian data, dan penarikan kesimpulan/verifikasi. ${ }^{10}$ Kondensasi data adalah proses pemilihan, pemfokusan, penyederhanaan, mengabstraksi, dan/atau mentransformasikan data dari catatan lapangan yang ditulis, transkrip wawancara, dokumen, dan bahan empiris lainnya. Penyajian data adalah sebuah pengorganisasian, penyatuan dan informasi yang memungkinkan penyimpulan dan tindakan. Kegiatan analisis yang ketiga adalah menarik kesimpulan dan verifikasi. Dari permulaan pengumpulan data, seorang penganalisis kualitatif mulai mencari arti benda-benda, mencatat keteraturan penjelasan, konfigurasikonfigurasi yang mungkin, alur sebab akibat, proporsi, kesimpulankesimpulan "final" mungkin tidak muncul sampai pengumpulan data berakhir, tergantung besarnya kumpulan-kumpulan catatan lapangan, pengkodeannya, penyimpanan, dan metode pencarian ulang yang digunakan, kecakapan peneliti, dan tuntutan-tuntutan pemberian data. ${ }^{11}$

10 Miles, B. Mathew, A. Michael Huberman, dan Johny Saldana, Qualitative Data Analysis A Methods Sourcebook,(America: Arizona State Unversity, 2014), 14.

${ }^{11}$ Ibid., 10. 


\section{HASIL DAN PEMBAHASAN}

Dalam penelitian ini, pengumpulan data yang digunakan yaitu teknik wawancara, observasi, dan dokumentasi. Berdasarkan ketiga teknik tersebut, diperoleh data tentang Pengembangan Kecerdasan Kinestetik Peserta Didik Melalui Kegiatan Ekstrakurikuler Tari Tradisional di Madrasah Ibtidaiyah Unggulan Al-Islah Kecamatan Muncar Kabupaten Banyuwangi Tahun Pelajaran 2018/2019, dengan hasil penelitian sebagai berikut:

\section{Pengembangan Kecerdasan Kinestetik Peserta Didik Melalui Kegiatan Ekstrakurikuler Unsur Wiraga Tari Tradisional di Madrasah Ibtidaiyah Unggulan Al-Islah Kecamatan Muncar Kabupaten Banyuwangi Tahun Pelajaran 2018/2019}

Unsur wiraga dalam tari tradisional merupakan olah gerak yang mengatur bagian-bagian tubuh. Berdasarkan hasil observasi peneliti, MI Unggulan Al-Islah Kecamatan Muncar merupakan sekolah yang memiliki kegiatan ekstrakurikuler tari tradisional yaitu tari gandrung dan tari kuntulan. Kegiatan tersebut bertujuan untuk mengembangkan kecerdasan kinestetik atau olah gerak peserta didik. Antusiasme peserta didik yang ingin mengikuti kegiatan ekstrakurikuler tari tradisional, walaupun banyak yang masih belum bisa menari dengan baik dan benar tetapi dilakukan latihan dengan cara terus menerus, akhirnya dapat menuai hasil yaitu perkembangan dari sisi olah gerak yang semakin hari semakin meningkat.

Sesuai dengan hasil wawancara, sebelum memasuki latihan awal menari gandrung dan kuntulan, peserta didik diajak luntuk memulai dengan pengenalan gerak dasar tarian tradisional yaitu seperti mendek, ngrayung, ngithing dan lain sebagainya. Lalu dilanjut untuk pembagian kelompokkelompok dari kelas II dan III lalu dari kelas IV dan V yang bertujuan agar terlihat kemampuan masing-masing dari individu peserta didik. kemudian dari setiap peserta didik diberi pekerjaan rumah berupa latihan sendiri tentang mendek, ngrayung dan lainnya dengan tujuan untuk lebih memantapkan kemampuan olah gerak masing-masing dari peserta didik. 
Setelah itu dilakukan pembiasaan senam pemanasan kemudian dilanjut berlatih gerakan demi gerakan yang dilakukan beberapa kali untuk mendapatkan gerakan dengan maksimal sesuai yang diinginkan dengan menirukan contoh gerakan dari guru pembimbing terlebih dahulu. Jadi guru pembimbing selalu melihat kemampuan peserta didik pada setiap pertemuan. Apabila kemampuan peserta didik dalam berlatih gerakan dapat melakukannya dengan baik maka akan dilanjutkan pada gerakan yang selanjutnya. Dengan begitu setiap proses ke proses pastinya akan menghasilkan sebuah perkembangan dari yang belum mampu untuk melakukan sampai mampu untuk melakukan gerakan-gerakan menari hingga selesai penguasaan gerakan.

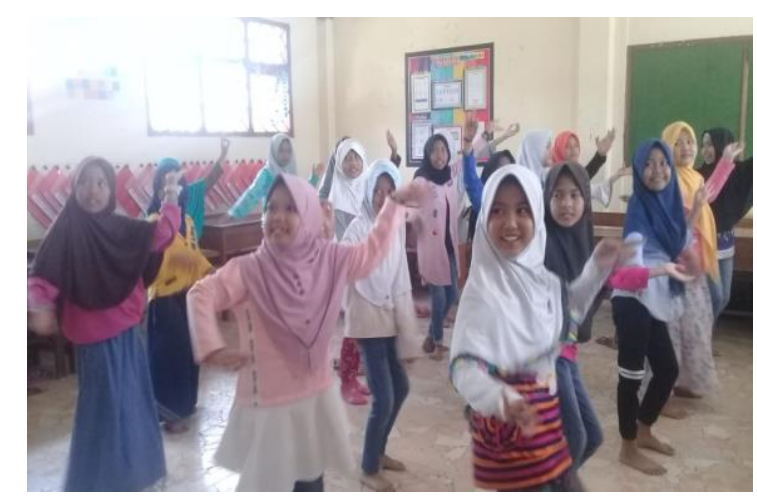

Gambar: Latihan Tari. ${ }^{12}$

Berdasarkan hasil wawancara dengan beberapa informan di atas dapat disimpulkan di dalam unsur wiraga atau yang disebut olah gerak dalam tari tradisional telah memberikan perkembangan dalam hal kecerdasan kinestetik dari peserta didik. Perkembangan yang dimaksud yaitu tentang gerakan-gerakan dalam tari tradisional yang dikuasai di bagian-bagian kaki, tangan, kepala. Dimana peserta didik dapat memiliki kemampuan koordinasi, kelenturan, dan kekuatan.

\footnotetext{
${ }^{12}$ Peneliti, Dokumentasi, Banyuwangi, 28 April 2019.
} 
Pengembangan Kecerdasan Kinestetik Peserta Didik Melalui Kegiatan Ekstrakurikuler Unsur Wirama Tari Tradisional di Madrasah Ibtidaiyah Unggulan Al-Islah Kecamatan Muncar Kabupaten Banyuwangi Tahun Pelajaran 2018/2019.

Unsur wirama dalam tari tradisional merupakan gerakan penari yang diselaraskan dengan alunan musik. Berdasarkan hasil observasi peneliti, peserta didik sebagai pemula dalam hal menari tari tradisional mengalami kesulitan menyesuaikan cepat lambatnya gerakan dengan alunan musik, menyesuaikan berganti gerakan dengan waktu yang tepat, dan menyesuaikan pukulan musik dengan gerakan-gerakan yang menbutuhkan kemantapan.

a. Mengatur antara cepat lambatnya gerakan menari dengan alunan musik

Berdasarkan hasil observasi, untuk melatih mengatur cepat lambatnya gerakan menari dengan alunan musik supaya selaras atau sesuai, dilakukan dengan latihan berkali-kali memakai hitungan dan perasaan.

b. Mengatur antara pergantian gerakan menari dengan waktu disaat musik yang tepat.

Berdasarkan hasil observasi, untuk melatih mengatur kapan pergantian gerakan menari dengan waktu disaat musik yang tepat, dilakukan dengan latihan berkali-kali menggunakan pola hitungan saja.

c. Mengatur keselarasan antara pukulan musik dengan gerakan-gerakan tertentu agar terdengar lebih mantap.

Berdasarkan hasil observasi, untuk melatih mengatur keselarasan antara pukulan musik dengan gerakan-gerakan yang agar terdengar lebih mantap, dilakukan dengan latihan berkali-kali memakai hitungan dan perasaan. 


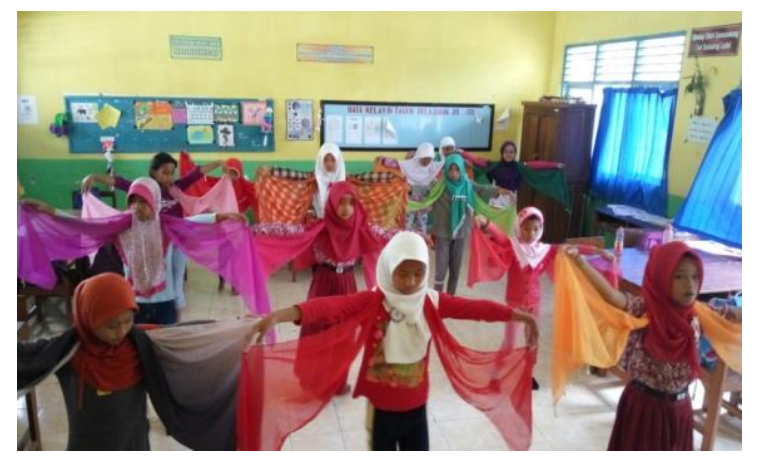

Gambar : Kegiatan mengatur keselarasan antara pukulan musik dengan gerakangerakan agar terdengar lebih mantap ketika melempar selendang. ${ }^{13}$

\section{Pengembangan Kecerdasan Kinestetik Peserta Didik Melalui Kegiatan}

\section{Ekstrakurikuler Unsur Wirasa Tari Tradisional di Madrasah}

\section{Ibtidaiyah Unggulan Al-Islah Kecamatan Muncar Kabupaten}

\section{Banyuwangi Tahun Pelajaran 2018/2019.}

Unsur wirasa dalam tari tradisional merupakan ekspresi wajah yang ditimbulkan dari kemampuan untuk mengahayati sebuah tarian Berdasarkan hasil observasi peneliti kegiatan latihan tari tradisional di MI Unggulan AlIslah Muncar, dilihat dari unsur wiramanya peserta didik sudah banyak yang mampu mengekpresikan wajahnya ketika menari.

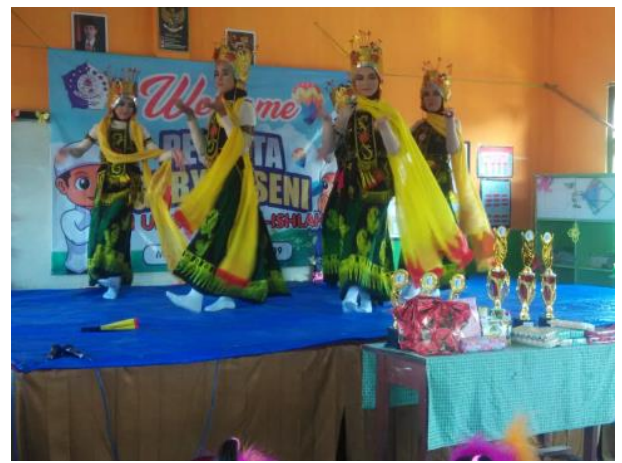

Gambar : Penampilan Tari Gandrung. ${ }^{14}$

\footnotetext{
${ }^{13}$ Peneliti, Dokumentasi, Banyuwangi, 21 April 2019.

${ }^{14}$ Peneliti, Dokumentasi, Banyuwangi, 4 Mei 2019.
} 
Berdasarkan hasil wawancara, cara melatih peserta didik ketika sebelum kegiatan ekstrakurikuler tari tradisional berlangsung, mereka dilatih untuk senam senyum yang dilakukan selama lima menit sampai seterusnya kondisional melihat dari sikap peserta didik. Senam senyum yang dilakukan terlihat benar jika peserta didiknya merasakan sakit di bibir dan pipinya, sebab rasa sakit tersebut menandakan akan senyum yang benar sebagaimana mestinya ketika menari akan tersenyum terus menerus. Senam senyum tersebut bertujuan untuk membuat peserta didik merasa terbiasa tersenyum ketika sedang menari. Senyum tersebut merupakan hal yang yang identik dengan tarian tradisional khusus dari banyuwangi yang mengambarkan betapa cantik, anggun nan elok dari paras sang penari. Pembiasaan senam senyum tersebut dilatihkan terhadap peserta didik tanpa pemberitahuan akan filosofi tarian yang akan ditarikan, karena dilihat dari kondisi peserta didik yang kebanyakan bercanda jadi tidak mampu untuk menangkap informasi asal usul yang disampaikan akan tarian tersebut.

\section{PEMBAHASAN}

Pengembangan Kecerdasan Kinestetik Peserta Didik Melalui Kegiatan Ekstrakurikuler Unsur Wiraga Tari Tradisional di Madrasah Ibtidaiyah Unggulan Al-Islah Kecamatan Muncar Kabupaten Banyuwangi Tahun Pelajaran 2018/2019

Sebelum memasuki tahap latihan mempelajari gerakan tari gandrung dan tari kuntulan, peserta didik diajari dengan pengenalan gerak dasar tari seperti ngrayung, nyekiting, mendek, dan lain sebagainya. Dimana bertujuan agar peserta didik mampu menguasai gerak dasar tari terlebih dahulu sebagai pondasi sebelum memasuki tahap berlatih tari gandrung dan tari kuntulan. Hal ini sesuai dengan teori yang dikemukakan dalam buku Fuji astuti, menjelaskan bahwa gerak tari adalah gerak yang telah mengalami 
perubahan dari yang awalnya gerak wantah ke gerak murni (nyekiting, nyempurit, ukel, dan lain sebagainya) kemudian menjadi gerak maknawi. ${ }^{15}$

Setelah itu pengembangan kecerdasan kinestetik peserta didik melalui kegaiatan ekstrakurikuler unsur wiraga tari tradisional dilakukan dengan cara yaitu melakukan pembiasaan senam pemanasan setiap sebelum berlatih. Lalu masuk ke tahap mempelajari gerakan- gerakan yang ada pada tari tradisional yang dipelajari. Senam pemanasan dan latihan gerakangerakan tersebut dilakukan oleh guru pembimbing terlebih dahulu kemudian peserta didik mengikutinya. Dengan cara tersebut, peserta didik dapat mempelajari untuk mampu menguasai gerakan demi gerakan. Hal ini sesuai dengan teori yang dikemukakan dalam buku Muhammad Yaumi, menjelaskan bahwa dalam mempelajari kecerdasan kinestetik, mereka melakukan tugas dengan baik setelah melihat orang lain melakukannya terlebih dahulu. kemudian meniru dan mengikutinya. ${ }^{16}$

Adapun perkembangan kecerdasan kinestetik yang didapatkan dari hasil latihan unsur wiraga tari tradisional adalah peserta didik mampu menguasai gerakan-gerakan di bagian-bagian tubuh seperti kaki, tangan, dan kepala. Hal ini senada dengan teori yang dikemukakan dalam buku Sumaryono, yang menjelaskan bahwa bagian-bagian tubuh yang diatur adalah:

a. Kaki (tekukan pada tungkai dan lututnya)

b. Tangan (ngruji, ngithing, nyempurit)

c. Kepala (mengangguk) ${ }^{17}$

Pengembangan Kecerdasan Kinestetik Peserta Didik Melalui Kegiatan Ekstrakurikuler Unsur Wirama Tari Tradisional di Madrasah Ibtidaiyah Unggulan Al-Islah Kecamatan Muncar Kabupaten Banyuwangi Tahun Pelajaran 2018/2019

${ }^{15}$ Astuti, Pengetahuan \& Teknik Menata Tari, 51.

16 Yaumi, Pembelajaran Berbasis Kecerdasan Jamak, 100.

${ }^{17}$ Sumaryono, Tari Tontonan, 67-73. 
Pengembangan kecerdasan kinestetik peserta didik melalui kegiatan ekstrakurikuler unsur wirama tari tradisional di Madrasah Ibtidaiyah Unggulan Al-Islah Muncar dilakukan dengan memperhatikan hal- hal berikut diantaranya yaitu:

a. Cepat lambatnya gerakan dengan alunan musik,

b. Menyesuaikan berganti gerakan dengan waktu yang tepat, dan

c. Menyesuaikan pukulan musik dengan gerakan-gerakan yang menbutuhkan kemantapan.

Hal tersebut kurang sesuai dengan teori yang dikemukakan dalam buku Astuti, menjelelaskan bahwa penyesuaian musik dengan gerakan tari berhubungan dengan seperti melakukan pindah posisi dari agem kiri ke agem kanan kemudian seledet kanan lalu kipek ke kiri. Sebelum penari melakukan pindah agem, ia harus mendengarkan gamelan untuk mencari angsel (transisi dinamika musik) yang tepat. Gerakan nyeledet dan kipek pun harus pas dengan pukulan tukang gendang sehingga gerakannya terlihat lebih mantap. ${ }^{18}$

Dalam melatih menyelaraskan gerakan dengan alunan musik, guru pembimbing ekstrakurikuler tari tradisional mengajarkan kepada peserta didik dengan cara menggunakan pola hitungan dan perasaan / feeling dari peserta didik. hal tersebut sesuai dengan teori yang dikemukakan dalam buku I wayan Dibia yang menjelaskan bahwa mengatur pola waktu (irama) dalam tari tidak selamanya harus ditandai oleh adanya ketukan. Irama bisa saja lahir dari detak (hati, jantung) yang dirasakan oleh penarinya. Jadi rasa irama itu bisa muncul secara alamiah. ${ }^{19}$

${ }^{18}$ Astuti, Pengetahuan \& Teknik Menata Tari, 10.

${ }^{19}$ Dibia, Buku Pelajaran Kesenian Nusantara, 135-136. 
Pengembangan Kecerdasan Kinestetik Peserta Didik Melalui Kegiatan Ekstrakurikuler Unsur Wirasa Tari Tradisional di Madrasah Ibtidaiyah Unggulan Al-Islah Kecamatan Muncar Kabupaten Banyuwangi Tahun Pelajaran 2018/2019

Pengembangan kecerdasan kinestetik peserta didik melalui kegiatan ekstrakurikuler unsur wirasa tari tradisional di Madrasah Ibtidaiyah Unggulan Al-Islah Muncar dilakukan menggunakan cara dengan pembiasaan senam senyum selama beberapa menit sebelum latihan gerakan dilaksanakan tanpa pemberitahuan akan filosofi tarian yang akan ditarikan. Hal tersebut tidak sesuai dengan teori yang dikemukakan dalam buku I Wayan Dibia, menjelaskan bahwa untuk memudahkan menjiwai suatu tarian dalam bentuk ekspresi wajah, seorang pemula hendaknya mengetahui latar belakang terciptanya dan karakter tarian tersebut. ${ }^{20}$

Namun perkembangan kecerdasan kinestetik yang didapatkan dari hasil latihan unsur wiraga tari tradisional adalah peserta didik mampu terbiasa berekspresi tersenyum ketika menari. Hal tersebut sesuai dengan yang dikemukakan dalam buku Sumaryono, menjelaskan bahwa penghayatan atau penjiwaan yang dalam tarian itu sebagai daya ungkap. Seperti dalam tari Jawa, ekspresi muka itu harus dikekang, terutama untuk karakter kalem misalnya tidak boleh seperti merengut, melotot-marah, tersenyum lebar. Dan lain sebagainya. ${ }^{21}$

Dari hasil temuan di atas menyatakan bahwa pengembangan kecerdasan kinestetik peserta didik melalui kegiatan ekstrakurikuler unsur wirasa tari tradisional dilakukan dengan pembiasan senam senyum tanpa pemberitahuan akan filosofi tarian yang ditarikan. Temuan lapang tersebut tidak sesuai dengan teori. Sedangkan perkembangan kecerdasan kinestetik peserta didik yang didapatkan dari latihan tari sudah sesuai dengan teori.

${ }^{20}$ Ibid., 136.

${ }^{21}$ Sumaryono, Tari Tontonan Buku Pelajaran Kesenian Nusantara, 83. 


\section{SIMPULAN}

Berdasarkan hasil penelitian yang telah dilakukan di Madrasah Ibtidaiyah Unggulan Al-Islah Kecamatan Muncar Kabupaten Banyuwangi tentang Pengembangan Kecerdasan Kinestetik Peserta Didik Melalui Kegiatan Ekstrakurikuler Tari Tradisional Tahun Pelajaran 2018/2019, dapat diambil kesimpulan sebagai berikut:

Pengembangan Kecerdasan Kinestetik Peserta Didik Melalui Kegiatan Ekstrakurikuler Unsur Wiraga Tari Tradisional di Madrasah Ibtidaiyah Unggulan Al-Islah Kecamatan Muncar Kabupaten Banyuwangi Tahun Pelajaran 2018/2019 dilakukan yaitu: a) Pengenalan gerak dasar, b) Pembiasaan senam pemanasan, c) Latihan gerakan satu persatu, d) Perkembangan kecerdasan kinestetiknya peserta didik dapat menguasai bagian-bagian tubuh seperti kaki, tangan, dan kepala. Sedangkan Pengembangan Kecerdasan Kinestetik Peserta Didik Melalui Kegiatan Ekstrakurikuler Unsur Wirama Tari Tradisional di Madrasah Ibtidaiyah Unggulan Al-Islah Kecamatan Muncar Kabupaten Banyuwangi Tahun Pelajaran 2018/2019 yaitu: a) Cara yang dilakukan saat latihan dengan menggunakan pola hitungan dan perasaan / feeling sebagai penari, b) Perkembangan kecerdasan kinestetiknya peserta didik mampu untuk menyeimbangkan gerakan tari dengan alunan musik. Adapun Pengembangan Kecerdasan Kinestetik Peserta Didik Melalui Kegiatan Ekstrakurikuler Unsur Wirasa Tari Tradisional di Madrasah Ibtidaiyah Unggulan Al-Islah Kecamatan Muncar Kabupaten Banyuwangi Tahun Pelajaran 2018/2019 yaitu: a) Cara yang dilukan saat latihan dengan pembiasaan senam senyum selama beberapa menit, b) Perkembangan kecerdasan kinestetiknya peserta didik mampu berkekspresi tersenyum ketika menari. 


\section{DAFTAR PUSTAKA}

Astuti, Fuji. Pengetauan \& Teknik Menata Tari Untuk Anak Usia Dini. Jakarta: Kencana, 2016.

At-Taubany, Trianto Ibnu Badar. Desain Pengembangan Kurikulum 2013 di Madarasah. Depok: Kencana, 2017.

B, Mathew, et, al. Qualitative Data Analysis. America: Arizona State University, 2014.

Baharuddin. Teori Belajar \& Pembelajaran. Yogyakarta: Ar-Ruzz Media, 2015.

Dibia, I Wayan. Buku Pelajaran Kesenian Nusantara Tari Komunal. Jakarta: Lembaga Pendidikan Seni Nusantara, 2006.

S, Alaik. 40 Hadits Shahih Teladan Hidup Sehat Rasulullah. Yogyakarta: Pustaka Pesantren, 2011.

Sumaryono. Tari Tontonan Buku Pelajaran Kesenian Nusantara. Jakarta: Lembaga Pendidikan Seni Nusantara, 2006.

Sugiyono. Metode Penelitian Pendidikan. Bandung: CV. Alfabeta, 2017.

Undang-Undang SISDIKNAS (Sistem Pendidikan Nasional) UU RI No. 20 Th. 2003, Jakarta: Sinar Grafika, 2008.

Yaumi, Muhammad. Pembelajaran Berbasis Kecerdasan Jamak. Jakarta: Kencana, 2016.

Masrukah, Wawancara Pra Penelitian, Banyuwangi, 18 Januari 2019.

Observasi di Banyuwangi 15 April 2019. 